\title{
A Primer on Exporting to Uruguay 1
}

\author{
Christina D. Storz, Timothy G. Taylor, and Gary F. Fairchild ${ }^{2}$
}

\section{Introduction}

Every year the U.S. Department of State publishes extensive Country Commercial Guides for a large number of countries. These guides provide a great deal of information useful to individuals interested in developing export markets either through direct exports or through direct foreign investment. This paper provides an abridged version of the Country Commercial Guide for Uruguay as well as supplemental information of direct relevance to agribusiness firms. It is hoped that the information contained in this report provides a useful starting point for individuals interested in exploring export or investment opportunities in Uruguay.

Note: County Commercial Guides are available for U.S. exporters from the National Trade Data Bank's CD-ROM or via the Internet. Please contact Stat-USA by telephone (1-800) STAT-USA for more information. Country Commercial Guides can be accessed via the World Wide Web at http://www.stat-usa.gov, http://www.state.gov, and http://www.mac.doc.gov. They can also be ordered as a hard copy or on diskette from the National Technical Information Service (NTIS) by telephone (1-800) 553-NTIS. American exporters seeking general export information/assistance and country-specific commercial information should contact the U.S. Department of Commerce, Trade Information Center by telephone (1-800) USA-TRADE; or by fax (202) 482-4473.

\section{Economic and Political Overview}

Uruguay is a founding member of the Southern Cone Common Market (MERCOSUR), comprising Argentina, Brazil, and Paraguay. Uruguay's capital, Montevideo, which is the seat of the MERCOSUR Secretariat, is located at the geographical center of MERCOSUR's most populated and wealthiest area. As such, it is a convenient hub for firms looking to service the MERCOSUR region.

Uruguay is a market-oriented economy in which the state still plays an important role. The economy performed well during most of the 1990s but went through a nearly five-year recession starting in late 1998, due to devaluation in Brazil, economic problems in Argentina, and an outbreak of foot-and-mouth disease. A sharp devaluation of the peso and a banking crisis in mid-2002 aggravated the recession and led to an historic $10.8 \%$ fall in GDP (Gross Domestic Product). In dollar terms, per capita GDP has fallen from US\$6,800 in 1998 to US\$3,500 in 2002. In mid-2002, the IMF and other international

1. This is EDIS document FE524, a publication of the Department of Food and Resource Economics, Florida Cooperative Extension Service, Institute of Food and Agricultural Sciences, University of Florida, Gainesville, FL. Published February 2005. Please visit the EDIS website at http://edis.ifas.ufl.edu.

2. Christina D. Storz, Research Assistant; Timothy G. Taylor, Professor; and Gary F. Fairchild, Professor, Department of Food and Resource Economics, Florida Cooperative Extension Service, Institute of Food and Agricultural Sciences, University of Florida, Gainesville, FL. 
financial institutions approved significant support for the government of Uruguay to address its balance of payments problems, banking crisis, and social issues. In 2003, the government of Uruguay signed a stand-by agreement with the IMF that is valid until March 2005.

In June of 2002, the government of Uruguay abandoned its long-standing exchange rate band, permitting the peso/dollar exchange rate to float freely. Although the depreciation of the peso has fostered exports, it has hurt dollar debtors' ability to honor their obligations and increased the inflation rate to $26 \%$. Uruguay's sovereign debt was rated "Investment Grade" between 1997 and 2001, but was downgraded several notches in 2002 and 2003 to near default levels. In May of 2003, the government implemented a successful voluntary debt exchange, which led to a significant improvement in the country risk rating.

The economic crisis has had a negative impact on Uruguay's traditionally strong social indicators and provoked substantial emigration. Although Uruguay's social indicators are still good by Latin American standards, recent government statistics show that poverty surged from $11 \%$ of households in 1998 to $15 \%$ in 2002.

The United States is Uruguay's fourth largest trading partner, following Brazil, Argentina, and the European Union. The United States exports mostly high-technology goods to Uruguay (machinery and computers), and imports mostly agricultural commodities (meat, wool, and leather). In 2002, the United States supplied 8\% of Uruguay's total imports, a significant reduction from the $12 \%$ peak of 1998 . The administration of President Jorge Batlle strongly favors expanding trade with the United States and other NAFTA countries. A U.S.-Uruguay Joint Commission on Trade and Investment was established in 2002 to broaden bilateral discussion and cooperation on economic and trade-related issues.

The best prospects for U.S. products continue to be chemicals (including agricultural), manufactured goods and machinery, transport equipment, food processing machinery, computer hardware and software, office machinery, environmental technologies, telecommunications, and medical and laboratory equipment. Uruguay's growing elderly population is a good market for geriatric equipment and services. The growth of tourism, forestry, and agribusiness (especially off-season fruit) also provide excellent opportunities for expanding U.S. exports. Similarly, opportunities for sales of equipment or services and investment exist in the construction and operation of power plants, airports, and forestry-related projects. Recent security concerns have led to increased demand for home safety deposit boxes and surveillance equipment.

\section{Marketing U.S. Products and Services}

There are a number of factors that should be considered in exporting products to Uruguay. This section provides a brief overview of many critical factors that must be considered.

\section{Establishing a Business}

The formation of a new enterprise or the acquisition of an existing Uruguayan company can be done freely. Shell corporations already formed but with no operations are also available for acquisition and can be purchased for about US $\$ 2,500$. It is advisable to contract an experienced attorney who can provide guidance in completing the legal paperwork required. The foreign investor is free to adopt any desired legal organization structure. The most usual form is a corporation or a branch, but a personal partnership is also possible.

\section{Distribution / Sales Channels}

All the customary import channels exist in Uruguay (agents, distributors, importers, trading companies, subsidiaries and branches of foreign firms). Sales outlets are usually traditional storefronts and supermarkets. No discount general merchandisers operate in Uruguay.

\section{Agents / Distributors: Finding a Partner}

A foreign supplier should be thorough in its selection of a local agent or representative. For this purpose, the supplier may wish to take advantage of the export promotion services provided by the U.S. 
Department of Commerce through the U.S. Embassy in Montevideo. One service, the International Partner Search (IPS), helps identify pre-screened and qualified partners, agents and/or distributors. The supplier should make clear in the contractual agreement between the parties whether the relationship is either employer-employee or commission-based. Failure to do so could result in supplier liability for severance and related benefits if he decides to end the relationship. A full list of services provided on behalf of the U.S. exporter is found online at http://www.usatrade.gov and http://www.export.gov.cs. Another useful website for U.S. exporters is http://www.export.gov.

\section{Performing Due Diligence}

Credit reports on Uruguayan firms may be obtained though the U.S. Embassy's International Company Profile (ICP) service for a US\$500 fee. To receive full details on how to order this service, please contact the Commercial Section in U.S. Embassy Montevideo (telephone 598-2-418-7777, extension 2322; fax 598-2-418-8581; e-mail montevideo.office.box@mail.doc.gov).

\section{Dlrect Marketing}

American exporters may sell and ship directly to Uruguayan consumers. Courier packages containing CDs, DVDs, books, and personal items valued at US $\$ 50$ or less are exempt from import tariffs. The relevant regulations, however, are not always uniformly applied and are changed periodically. Telemarketing and e-mail campaigns are on the rise. Direct marketing is also popular in heavily transited street corners where hired promoters distribute flyers and samples of all types of products and services. Inserts in the Sunday edition of major newspapers are also a popular form of direct marketing. Catalog sales are not common as Uruguayan shoppers prefer to window shop and personally choose the goods to be purchased.

\section{Franchising}

Franchising in Uruguay has to-date been largely limited to food-related outlets, hotels, car rental companies, and some retail clothing stores. There are no legal restrictions on operating a franchise in
Uruguay. Contact the Uruguayan Franchising Association to learn more about franchising in Uruguay (telephone/fas 598-2-418-5189; e-mail milbea@adinet.com.uy ).

\section{Joint Ventures / Licensing}

Both joint ventures and licensing are common in Uruguay and generally involve procedures similar to those practiced in most other countries.

\section{Selling Factors / Techniques}

Foreign manufacturers with sustained sales in Uruguay generally use the services of an agent or distributor. Practically all importers/distributors are based in Montevideo, although some maintain sales networks in the interior of Uruguay. A U.S. firm with a local representative has the advantage of keeping up-to-date with local market conditions as well as any changes in policies affecting trade.

When making purchase decisions, Uruguayan consumers consider quality, price, payment terms, delivery time, after-sales servicing, and compatibility with existing systems. American manufactured products are generally regarded as high in quality and competitive in price. However, they are sometimes rated low when it comes to financing, which is an important factor in sales in Uruguay. American manufacturers offering flexible, innovative, and competitive credit terms will overcome a difficult hurdle in achieving export sales to Uruguay.

\section{Advertising / Trade Promotion}

The cost of advertising in Uruguay has dropped in dollar terms following the peso's 2002 devaluation. It is advisable to work with a local advertising agency. El Pais and El Observador are the leading newspapers in terms of circulation; Busqueda and Crónicas Económicas are highly respected weekly journals. Several major international advertising agencies maintain offices in Montevideo. Television and radio advertising are also popular. During the summer months of December to March, light aircrafts with banners are commonly used to promote new products along the coast. Several local ad agencies produce TV commercials for clients abroad. 
The Embassy periodically hosts industry-specific catalog exhibitions and trade missions. It also participates with a commercial booth in some trade fairs. Details concerning these fairs may be obtained from the Commercial Section, U.S. Embassy in Montevideo (telephone 598-2-418-7777, extension 2325; fax: 598-2-418-8581; e-mail montevideo.office.box@mail.odc.gov).

\section{Sales Support / Customer Service}

Uruguayans consider sales support and customer services important factors when deciding which products to buy. American manufacturers should seriously consider using an agent in Uruguay to provide customer support services. Company representatives resident in neighboring countries are less effective. A local U.S. firm is selling warranty protection that supplements that provided by the original equipment manufacturer.

\section{Product Pricing}

The Uruguayan market price structure reflects world market prices plus import tariffs and transportation costs. In addition to tariff advantages, products from nearby MERCOSUR countries, like Argentina and Brazil, enjoy significantly lower transportation costs than do products from the United States, Europe, and Asia.

\section{Selling to the Government}

Although U.S. companies may sell directly to the Uruguayan government, it is useful to have a registered local representative. Registration takes place once a year during a specified period in which interested parties may inscribe themselves in the list of official government suppliers. Companies should consider providing product literature and price quotations to selected government purchasing offices and the different state-owned entities; these offices and entities frequently refer to literature on hand when drafting the specifications for their procurement tenders. Government entities usually do their own procurement. Uruguayan law requires that there be public bids for large purchases. Nevertheless, procurement by negotiation is permitted in certain cases. A G2B website has been established to increase transparency and reduce government procurement costs. Because of severe budget cutbacks, however, most government procurement has been put on stand-by.

\section{Need for a Local Attorney}

It is advisable to obtain the services of a local attorney before setting up operations or carrying out substantial business transactions in Uruguay. Local attorneys can be very helpful in sorting through bureaucratic red tape, which may otherwise be frustrating for a newcomer. A free list of local attorneys may be obtained from the U.S. Embassy's Consular Section (telephone 598-2-418-7777, extension 2362; e-mail montevideo.office.box@mail.doc.gov).

\section{Agribusiness Industry Prospects}

Exports of food products to Uruguay have good potential. Imported food products for mass consumption are typically purchased from Argentina, Brazil, and Chile, while imports from Europe and the United States are aimed at the middle and high income sectors. American companies with competitive prices should consider tapping the mass market through the development of the private label concept.

\section{Trade Regulations and Standards}

\section{Trade Barriers}

Tariffs on non-locally-produced raw materials, intermediate goods and consumer goods range from $2 \%$ to $6 \%, 8 \%$ to $16 \%$, and $10 \%$ to $20 \%$, respectively.

Quotas were eliminated in the mid-1970s and non-tariff barriers, including reference and minimum import prices, were substantially reduced in the 1990s. Certain imports (e.g., fertilizers, vegetable products, and frozen embryos) require special licenses or Customs documents. Bureaucratic delays may also add to the cost of imports, although importers report that a "de-bureaucratization" commission has improved matters.

Uruguayan importers are required to pay a $4 \%$ ad valorem tax on all freight arriving via foreign-registered airlines. Freight that arrives by the national airline, PLUNA-VARIG, is exempt from the 
tax. A civil aviation agreement between Uruguay and the United States provides for equal treatment between U.S. and Uruguayan airfreight carriers. American carriers are therefore also exempt from this tax.

\section{Customs Valuation}

Uruguay's tariff structure follows the harmonized system (HS) of tariff nomenclature. All Customs duties, surcharges, service, and other charges are consolidated in a Customs unified rate or "tasa global arancelaria" (TGA).

The Office of the Director General of Customs may apply Customs valuation when there is a question concerning a supplier's classification and/or valuation. Valuation criteria are those followed by the World Trade Organization (WTO). Over or under invoicing, false declarations as to the quantity, quality, or types of goods, or incorrect classifications under the harmonized code are considered fraud and subject to legal penalties.

\section{Standards}

Uruguay uses the metric system of weights and measures. The Laboratorio Tecnologico del Uruguay (LATU) is the officially approved agency that controls standards and quality control of imports and exports. A national quality committee reviews and recommends issuance of ISO 9000/9001 certificates, if warranted. The Uruguayan Institute of Technical Norms (UNIT) carries out certification and elaborates technical norms. It is the exclusive representative of ISO, IEC, and the World Quality Council (WQC) in Uruguay.

\section{Labeling Requirements}

Labeling and marking requirements are set and controlled by two federal agencies and several municipal offices. Basically, labels must contain a Spanish-language description of the main ingredients of the product, its country of origin, expiration date, net weight, and the full name and address of the Uruguayan importer (plus validity and cooking instructions in the case of foodstuffs). Imported products may include the original label of the country/language of origin but should have a sticker/label attached to the package with the information requested above. Manuals, product literature, and other written materials, while not required, will be more useful if written in Spanish. A new consumer defense law, approved in 2000, regulates labeling requirements.

\section{Temporary Entry Provisions}

Products may be imported under temporary admission or drawback provisions. Products imported under temporary admission provisions are exempt from import duties but must be re-exported within 18 months.

\section{Import Controls}

Goods entering from MERCOSUR countries generally pay no tariffs. MERCOSUR member countries agreed on a Common External Tariff (CET) in December of 1994. On January 1, 1995, the CET entered into effect on imports from non-member countries, with rates ranging (with some exceptions) between 0 and $20 \%$.

All MERCOSUR countries have requested CET exceptions. Uruguay applies preferential tariffs on the import of vehicles and supplies for agriculture, forestry, and hotels. The Uruguayan government also gives special treatment to imports of raw materials for the production of export goods. Moreover, in December of 2001, the Uruguayan Government unilaterally decided not to increase tariffs on capital goods as mandated by the MERCOSUR convergence schedule for the CET. In the vast majority of the exceptions being requested by Uruguay, the Uruguayan Government applies import tariffs that are lower than the bloc's CET.

In addition to tariff rates, a (refundable) value-added tax of $33 \%(23+5+5)$ is applied over Customs valuation plus import surcharges. Import duties range from $0 \%$ to $23 \%$.

Only commercial firms, industrial firms or individuals listed in the registry of importers may legally import products into Uruguay. No uncommon documents are required to import merchandise. 
Certain imports require special licenses or Customs documents. Among these are frozen embryos, livestock, bull semen, anabolics, sugar, seeds, hormones, meat and wheat.

There are no special import provisions or restrictions. All goods may be imported except for a very limited list of goods that may require special authorization. From time to time, the government bans the importation of certain food articles originating from areas declared by the World Health Organization to be unfit. The municipality of Montevideo imposes strict, and at times, outdated and arbitrary regulations regarding the composition of food articles (e.g., dyes).

\section{Export Controls}

Other than permits for the export of certain works of art or antiques, there are no export controls currently in force. The export sales of certain domestic products enjoy tax exemptions and special credits.

\section{Membership in Free Trade Agreements}

Uruguay is a member of the WTO and the Latin American Integration Association (ALADI). It holds numerous bilateral trade agreements with ALADI partners. The Uruguayan government is currently trying to broaden a comprehensive trade agreement signed with Mexico in 1999. Uruguay is a founding member of the Southern Cone Common Market (MERCOSUR). Other members of MERCOSUR are Brazil, Argentina, and Paraguay, with Chile and Bolivia as associate members. Montevideo is the headquarters of MERCOSUR's Secretariat. Uruguay also holds separate trade arrangements for certain products with Brazil and Argentina (called PEC and CAUCE, respectively) that are periodically renewed.

\section{Investment Climate in Brief}

- In 1998, the Uruguayan government approved an investment promotion and protection law (Number 16906) that declares that the promotion and protection of national and foreign investment is in the Uruguay's interest. The main aspects of the law are that foreign and national investments are treated alike, that investments are allowed without prior authorization or registration, that the Government does not prevent the establishment of investments in the country, and that investors may freely transfer abroad their capital and profits from the investment. There are no restrictions on technology transfer. In June of 2003, the government established a single-window mechanism to channel all investment requests, with $100 \%$ foreign ownership permitted, except where restricted for national security purposes.

- Although U.S. firms have not encountered major obstacles in Uruguay's investment climate, some have been frustrated by the length of time it takes to complete bureaucratic procedures and by the numerous changes in rules or new taxes since 2001.

- Uruguay has maintained a long-lasting tradition of imposing no restrictions on the purchase of foreign currency or the remittance of profits abroad. Foreign exchange can be freely obtained.

- In the event of expropriation, the Uruguayan constitution provides for the prompt payment of fair compensation. There have been no expropriation actions taken in the recent past.

- There are no laws that force local ownership, except in the areas reserved for the State.

- An investor is given the option of choosing between arbitration and recourse to the courts for the settlement of disputes.

- There are no specific performance requirements on which foreign investment is conditioned.

- There are no restrictions on private ownership; the establishment of a business; or engaging in any form of remunerative activity, except in areas declared to be of national security interest or those in which the government maintains a legal monopoly.

- Secured interests in property, both movable and real, are recognized and enforced.

- Laws and procedures regulating foreign investment are transparent and streamlined. However, from time to time, the government allows debtors (especially those in the 
agriculture and mortgage sectors) to refinance their debts on very favorable terms and conditions.

- Foreign investors have easy access to credit on market terms. Although the private sector has access to a variety of credit instruments, access to long-term credits in the local banking sector may be difficult.

- There have been no significant incidents involving politically motivated damage to property or installations. Uruguay is a stable democracy where respect for the rule of law is the norm and where most of the population is committed to non-violence.

- Uruguay has strong laws to prevent bribery and other corrupt practices. In 2002, Uruguay was ranked 32nd in Transparency International's Corruption Perception Index (second best after Chile in Latin America). American firms have not identified corruption as an obstacle to foreign direct investment.

- The Uruguayan government signed an investment insurance agreement with the Overseas Private Investment Corporation (OPIC) in December of 1982. The agreement allows OPIC to ensure U.S. investments against risks resulting from expropriation, inconvertibility, war, or other conflicts affecting public order. OPIC programs are currently used in Uruguay.

- On June 20, 2002, the Uruguayan Government eliminated its decade-long exchange rate regime policy and allowed the peso to float freely.

- The Uruguayan labor force of some 1.2 million is well educated and adept in the application of modern industrial techniques. The government has instituted technical training programs to help meet industries' skilled labor requirements. At 97\%, Uruguay's literacy rate is the highest in Latin America and on par with that of the United States.

\section{Business Customs}

\section{Travel Advisory and Visas}

American citizens need a valid U.S. passport, but visas are not required for holders of regular passports. Those traveling on diplomatic or official passports must have a valid visa in addition to the passport. Travel advisories, if any, can be accessed online at http://uruguay.usembassy.gov or http://travel.state.gov.

Business and tourist stays are limited to 90 days and may be extended for an additional 90 days.

No inoculations are currently necessary for entry. International travelers are advised to contact their local public health department, physician, or travel agent at least two weeks before departure to obtain current information on health requirements.

\section{Business Infrastructure}

Business dress and appearance, as well as approach to business relations, should be very conservative. An advance appointment for a business visit is usually necessary and considered a customary courtesy. Punctuality is generally observed. Typically, business is discussed after social amenities. Business cocktails and lunches are common. Business breakfasts are uncommon.

Normal business hours are 9:00 a.m. to 7:00 p.m., Monday through Friday. Banks observe public hours 1:00 p.m. to 5:00 p.m., Monday through Friday. Stores are also open on Saturdays 9:00 a.m. to 1:00 p.m. Shopping centers are open every day 10:00 a.m. to 10:00 p.m.

International telephone and fax services are efficient but expensive. Uruguay's telephone system is fully digitized. There is widespread use of cellular phones. International phone cards with "Dial-USA" features (e.g., AT\&T, MCI, and Sprint) are accepted.

Montevideo has several five-star category hotels. There are five U.S.-managed hotels in Montevideo (Sheraton, Radisson, Holiday Inn, Best Western, and Days Inn) and four in the seaside resort of Punta del Este (Conrad-Hilton, Days Inn, Best Western, and Choice). 
Several airlines have service to Montevideo's

Carrasco International Airport from Europe and other parts of Latin America. There are currently two daily U.S.-carrier (American Airlines and United Airlines) flights to and from the United States. Both flights have a stopover in Buenos Aires. Internal transportation is mainly by car or bus. Within Montevideo, bus and taxi services are extensive, safe and inexpensive.

Uruguay observes standard time (GMT-3), which is either one or two hours ahead of Eastern Standard Time, depending on U.S. Daylight Savings Time.

\section{Useful Web Sites}

\section{URUGUAY:}

- US Embassy-Montevideo http://uruguay.usembassy.gov

- Office of the Director General of Customs http://www.aduanas.gub.uy

- MERCOSUR http://www.mercosur.org

- Organizationfor the Service of Uruguayan Agribusiness (Camara Mercantil de Productos del Pais) http://www.davanet.com.uy/camaramercantil/ indexing.htm

\section{UNITED STATES:}

- USDA Foreign Agricultural Service http://www.fas.usda.gov

- US Export Programs Guide http://infoserv2.ita.doc.gov/ticwebsite/tic.nsf/ AF34FA880278BDD5825690D00656C6F/ F69FDCF72B7713B58525691900746F18?Open Document

- Internet Guide to Trade Leads http://infoserv2.ita.doc/gov/ticwebsite/tic.nsf/ 504ca249c786e20f85256284006da7ab/ ef7db94aef24919885266470049c1cd?OpenDocu ment

- US Trade Finance Resources http://infoserv2.ita.doc.gov/ticwebsite/tic.nsf/
AF34FA880278BDD5825690D00656C6F/ F69FDCF72B7713B58525691900746F18?Open Document

- Basic Guide to Exporting http://www.unzco.com/basicguide/index.html

\section{HEMISPHERIC:}

- Hemispheric Guide on Customs Procedures http://alca-ftaa.iadb.org/hgcp_eng.htm

- Hemispheric Trade and Tariff Database http://alca-ftaa.iadb.org/eng/ngmadb_e.htm 